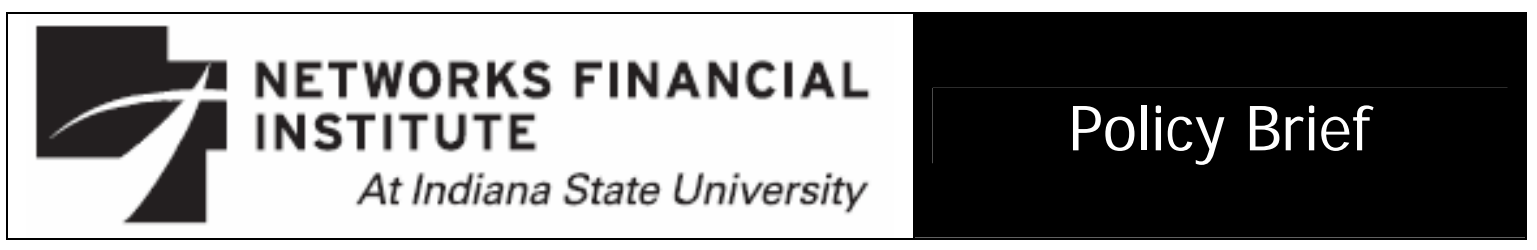

2007-PB-04

March 2007

\title{
Optional Federal Chartering of I nsurance: Design of a Regulatory Structure
}

\author{
Hal S. Scott
}

Abstract: This paper examines the design of a federal regulatory structure for insurance companies in the United States, assuming some form of an optional federal charter is adopted. Any design must take account of the objectives of insurance regulation, the convergence of financial service powers among banks, securities, and insurance firms, the types of lines to be regulated at the federal level, and problems posed by the possible participation of nationally chartered insurers in state residual pools and guaranty funds.

This paper argues that the creation of a new federal insurance regulator should be accompanied by more consolidation and less fragmentation in the overall federal regulatory structure, by placing the new regulator within an operationally strengthened President's Working Group on Financial Markets.

Ideally, a new optional federal charter should provide a real federal option by having the federal government fully regulate the safety and soundness and product lines of all insurers choosing the federal option. However, if lines were to be split between federal and state regulation, safety and soundness regulation of all insurance companies choosing a federal option should take place exclusively at the federal level, leaving the states with responsibility for consumer protection regulation in non-federal lines. While state guaranty funds have functioned effectively overall, a national guaranty fund would have the advantage of uniting responsibility for insurance and safety and soundness regulation, as in the case of banking.

About the Author: Hal S. Scott is the Nomura Professor and Director of the Program on International Financial Systems at Harvard Law School. He is the Director of the Committee on Capital Markets Regulation, a member of the Shadow Financial Regulatory Committee. He is past Governor of the American Stock Exchange (20022005). He has served as a consultant to a variety of financial institutions, multilaterals and governments.

Keywords: insurance reform, regulation, optional federal chartering

The views expressed are those of the author and do not necessarily reflect official positions of Networks Financial Institute. Please address questions regarding content to Hal S. Scott at hscott@law.harvard.edu. Any errors or omissions are the responsibility of the author.

NFI working papers and other publications are available on NFI's website

(www.networksfinancialinstitute.org). Click "Research" and then "Publications/Papers." 


\section{Optional Federal Chartering of I nsurance: Design of a Regulatory Structure \\ Hal S. Scott ${ }^{*}$}

Since the early nineteenth century, states have preempted federal authority

(reverse preemption) in the regulation of the U.S. insurance industry. In contrast to other

financial services (i.e., securities and banking), Congress has not sought to exercise either concurrent or preemptive authority over insurers. Indeed, the McCarran-Ferguson Act of 1945 explicitly found state regulation of insurance to be in the public interest, and provided that no federal law should be found to "invalidate, impair, or supersede" any state insurance regulation or tax. ${ }^{1}$ Recently, however, and particularly in the wake of the Gramm-Leach-Bliley Act of $1999,{ }^{2}$ many insurers have proposed a system of optional federal chartering and regulation of insurance (OFC).

In April 2006, Senators John Sununu and Tim Johnson introduced S. 2509, the National Insurance Act of 2006 ("NIA"), ${ }^{3}$ which sets forth a scheme for federal chartering for life and property/casualty insurers largely modeled on the National Bank

Act of $1864 .^{4}$ In September 2006, Representative Ed Royce introduced a companion bill, H.R. $6225 .^{5}$ In contrast to the state coordination approach taken by the State Modernization and Regulatory Transparency (SMART) Act introduced by

\footnotetext{
* I want to thank my two research assistants, Vincent Cannon and Colin Lloyd, for their substantial and valuable contributions to this paper. This paper was prepared for "4th Annual Insurance Reform Summit" a conference sponsored by Networks Financial Institute at Indiana State University held in Washington D.C. on March 2007.

${ }^{1}$ Pub. L. 15, March 9, 1945. (Codified at 15 U.S.C. $\left.\S \S 1101-1115.\right)$

${ }^{2}$ Pub. L. 106-102, Nov. 12, 1999.

${ }^{3}$ S. 2509, 109th Cong. 2d. Sess., April 5, 2006.

${ }^{4}$ Act of June 3, 1864, c. 106, 13 Stat. 99, as amended. (Codified at 12 U.S.C. $\S \S 1-548 ; 19$ U.S.C. $\S 197$; 31 U.S.C. $\S 543.38$.)

${ }^{5}$ H.R. 6225, 109th Cong. 2d Sess., Sept. 28, 2006.
} 
Representatives Michael Oxley and Richard Baker in March 2004, ${ }^{6}$ NIA would establish a "comprehensive system of Federal chartering, licensing, regulation and supervision" for insurance companies and agents. ${ }^{7}$ State regulation would be preempted except in a few areas, such as taxation and participation of national insurers in state residual risk mechanisms and guaranty funds. ${ }^{8}$

The merits of OFC have been much debated; however, comparatively little consideration has been given to the matter of how such a system should function if enacted. ${ }^{9}$ This paper considers the proposal by Senators Sununu and Johnson, and the issues raised by the need to design an appropriate regulatory structure for OFC. Ultimately, the design of a regulatory structure must turn on the objectives of federal insurance regulation and the lines of insurance to be regulated.

\section{Current Proposal: National Insurance Act of 2006}

We begin with a summary of the approach of the NIA to federal chartering. The NIA would establish an Office of National Insurance within the Department of the Treasury to provide federal chartering for life and property/casualty insurers. The Office would be headed by the Commissioner of National Insurance, the insurance counterpart to the Comptroller of the Currency, who would be authorized to issue federal charters and

\footnotetext{
${ }^{6}$ In June 2006, Rep. Ginny Brown-Waite introduced part of the SMART Act as H.R. 5637. $109^{\text {th }}$ Cong. $2 d$ Sess., June 19, 2006.

${ }^{7}$ NIA, $\S 2$.

${ }^{8}$ Id., at $\$ \S 1125,1703$.

${ }^{9}$ Scott Harrington provides an overview of options for federal intervention in insurance regulation, and suggests two alternatives to OFC: (1) federal minimum standards that would preempt inadequate state regulation, or (2) the creation of a system of "primary state" chartering akin to the current system of corporate chartering. See Federal Chartering of Insurance Companies: Options and Alternatives for Transforming Insurance Regulation, Networks Financial Institute Policy Brief, No. 2006-PB-02 (March 2006) 25-30.
} 
licenses to insurers, and to regulate exclusively their operations and solvency. ${ }^{10}$ The Commissioner would have the power to implement the NIA by regulation, and would "have exclusive authority to determine whether a person subject to this Act has complied with the Act or the application of any State law to matters regulated under this Act, including the determination of any complaint raised by any person."11 Thus, the NIA apparently would provide national insurers with "visitorial protection" analogous to that granted to national banks.

Like the Office of the Comptroller of the Currency, the Office of National Insurance would be self-funding. The NIA provides that the Office would be funded by the examination fees paid by national insurers and agents, as well as "such additional fees as the Commissioner determines to be necessary and appropriate to fund the expenses of the Office." 12

The NIA would eliminate prior approval of policy form and rate regulation for nationally licensed lines of life and property/casualty insurance. It would establish a "file and use" system for life insurance forms, and allow national life insurers to classify policyholders and set rates freely. ${ }^{13}$ National property/casualty insurers would be subject to a "use and file" system, and be free from any requirement by the Commissioner that they use "any particular rate, rating element, price, or form."14

National insurers still would be required to comply with state law prescribing compulsory coverage requirements for workers' compensation and individual auto

\footnotetext{
${ }^{10}$ NIA, $\S 2(3)$.

${ }^{11}$ NIA, § 1102(b)(1)(A)(iv) \& (b)(2)(A).

${ }^{12} I d ., \S 1122$.

${ }^{13} I d ., \S 1213$.

${ }^{14} I d ., \S 1214$.
} 
insurance, ${ }^{15}$ and to participate in state mandatory residual risk mechanisms and guaranty funds. ${ }^{16}$ However, under the Act, no state would be empowered to regulate the rates at which a national insurer might offer workers' compensation or auto insurance, or to require a national insurer to participate in any residual risk mechanism that would "fail to cover the expected value of all future costs" associated with it. ${ }^{17}$ Also, the Commissioner would have to certify that each state guaranty fund fairly represents insurers by size and product line, and does not discriminate against national insurers. ${ }^{18}$ If the state guaranty fund did not qualify for certification, a national insurer operating in that state would join the National Insurance Guaranty Corporation established by the NIA instead. ${ }^{19}$

Internally, the Office of National Insurance would contain a Division of Insurance Fraud, a Division of Consumer Affairs, and an Office of the Ombudsman. The Division of Insurance Fraud would be charged with investigating fraudulent insurance acts and enforcing civil penalties for violations of the law. ${ }^{20}$ The Division of Consumer Affairs would implement and enforce market conduct regulations. ${ }^{21}$ The Office of the Ombudsman would act as a liaison between the Office of National Insurance "and any person adversely affected by the Office's supervisory or regulatory activities, including the failure of the Office to take a requested action." ${ }^{22}$ In addition, the Commissioner would have the authority to provide for the registration of a national insurance selfregulatory organization. ${ }^{23}$

${ }_{16}^{15}$ d., $§ 1125(\mathrm{~b})(4)$.

${ }^{16}$ Id., § 1125(b)(3) \& 1601(a).

${ }^{17}$ Id., $§ 1125(\mathrm{~b})(3) \&(4)$.

${ }^{18} I d ., \S 1602$.

${ }^{19} \mathrm{Id}$., $\S 1601(\mathrm{~b})$.

${ }^{20} I d ., \S 1104$.

${ }^{21} I d ., \S 1105$.

${ }^{22}$ Id., $\$ 1107(\mathrm{~b})$.

${ }^{23} I d$., § 1106. 


\section{Objectives of Insurance Regulation}

The business of insurance is "affected with a public interest." 24 For this reason, insurance companies and agents in the U.S. have been regulated since the colonial period. ${ }^{25}$ Generally, state regulation has had two critical concerns: financial solvency and consumer protection. First, because insurance companies promise to provide insured persons or their beneficiaries with future benefits, regulators seek to ensure their stability and financial soundness. Second, because most insurance policy holders generally are unfamiliar with insurance contracts and lack complete information about insurance products, regulators seek to insure that policy holders receive fair and equitable treatment. Both rationales come down to consumer protection because, unlike banks, insurance company failures do not raise concerns about systemic risk.

A central part of insurance regulation is the enforcement of laws mandating insurance coverage and prohibiting "excessive, inadequate or unfairly discriminatory" rates. $^{26}$ The central purpose of rate regulation long has been the protection of consumers against prices "formed in the councils of the underwriters [and] promulgated in schedules of practically controlling constancy which the applicant for insurance is powerless to oppose. 27 Similarly, the perceived quasi-public character of insurance has led to the creation of residual market mechanisms like assigned risk pools. ${ }^{28}$ The perceived

\footnotetext{
${ }^{24}$ German Alliance Ins. Co. v. Kansas, 233 U.S. 389, 406 (1913).

${ }^{25}$ Colonial insurance companies were chartered under the British Crown. In 1792, Pennsylvania became the first state to charter insurance companies, and the several states soon followed suit. See, Justin L. Brady, et al., THE REGULATION OF INSURANCE (1995) 34-35.

${ }^{26}$ See, e.g., N.Y. Ins. L. $§ 2301$.

${ }^{27}$ German Alliance Ins. Co., 233 U.S. at 416.

${ }^{28}$ See, e.g., N.Y. Ins. L.§ 2318.
} 
"monopolistic character" 29 of the business of insurance has been used by regulators to justify prior approval or review of product design and pricing, as well as the pooling of insureds. ${ }^{30}$

\section{Rationale for Optional Federal Chartering}

The debate over optional federal chartering of insurance has elucidated a number of goals and concerns that may serve as guideposts for a designer of a federal insurance regulator. The "dos" and "don'ts" of federal insurance regulation can provide a rubric for evaluating the different options for structuring the regulator.

First, the federal regulator should decrease costs of regulation by ensuring uniformity and achieving economies of scale. One of the rationales for a federal option is the avoidance of different compliance requirements imposed by each of the fifty-one state regulators. In order to realize this benefit fully, not only must federal regulation of federally chartered insurers preempt most state regulation, but it should also be sufficiently centralized at the federal level that insurers do not face overlapping obligations from different federal regulators.

Cost-savings from uniformity and centralization are also relevant for the government and taxpayers. Currently, there is a significant degree of duplication of regulatory functions by different state regulators. For instance, a nationwide auto insurance company might be subject to inconsistent minimum capital requirements by regulators in the states in which it is licensed. Each regulator is responsible for

\footnotetext{
${ }^{29}$ German Alliance Ins. Co., 233 U.S. at 416. Notwithstanding this perception, most modern insurance markets would be considered competitive. See, e.g., Martin F. Grace \& Michael M. Barth, The Regulation and Structure of Nonlife Insurance in the United States, World Bank Financial Sector Development Working Paper 1155 (July 1993) 1; and, Harrington, Federal Chartering of Insurance Companies, supra note 9 , at 5 .

${ }^{30}$ For example, Massachusetts requires "unisex" rates for certain kinds of insurance. See, Peter M. Lencsis, INSURANCE REGULATION IN THE UNITED STATES: AN OVERVIEW FOR BUSINESS AND GOVERNMENT (1997).
} 
safeguarding the solvency of the company. In contrast, if the company were federally chartered, a single federal regulator could subject these insurers to a single, uniform capital standard. Furthermore, the federal regulator should be designed so as to minimize duplication of such functions as examination, investigation, and enforcement. There is, however, cause to be wary that any new federal agency will try to expand its jurisdiction and influence by creating a new unnecessary bureaucracy. This possibility argues in favor of effective political oversight.

Second, the federal regulator should encourage appropriate deregulation. As Scott Harrington has observed, state insurance commissions engage in an excessive amount of regulation. He highlights such examples as approval of policy forms, approval of rate changes, restrictions on underwriting and risk classification schemes, and mandated benefits. ${ }^{31}$ Much of this regulation is unwarranted except on distributive grounds. This is an entirely different objective than consumer protection. In fact, such regulation is costly for consumers as it leads to distortions in the insurance market. For instance, although restrictions on rate variation across geographic regions in a state might lower premiums for high risk consumers, they do so by increasing premiums for low risk consumers. $^{32}$ This smoothing effect decreases incentives for high risk consumers to control their risks, thereby increasing losses and premiums for the entire insured population. $^{33}$

If a federal regulator is to achieve reduction in regulatory redistribution, it should be insulated from the incentives that lead to such regulation. The national scope of federal regulation itself is likely to reduce some of these incentives, such as pressure to

\footnotetext{
${ }^{31}$ Harrington, Federal Chartering of Insurance Companies, supra note 9, at 6-7.

${ }^{32} \mathrm{Id}$., at 14 .

${ }^{33} \mathrm{Id}$., at 15 .
} 
cross-subsidize groups within states. On the other hand, pressures could increase at the federal level to cross-subsidize groups among states. Generally, these pressures would be decreased by insulating a regulator from political pressure through the creation of an independent agency; however, this approach raises problems of its own, explored below.

Third, the federal regulator should establish an even playing field with other regulated financial institutions, like banks, securities firms, and foreign insurance firms. Due to the multiple compliance costs and arguably excessive regulation of the present system, banks, securities firms, and foreign insurance companies, have a competitive advantage. After the enactment of the Gramm-Leach-Bliley Act, banks began to compete directly with insurance companies in offering insurance products, leading insurance companies to complain that they were at a "severe competitive disadvantage" because banks face less burdensome regulation with a "vastly shorter timetable" for new product approvals. ${ }^{34}$ A federal regulator should be sensitive to these competitiveness concerns and, where possible, coordinate its activities with those of other regulators to ensure a level playing field. A federal regulator cannot achieve an even playing field objective if it is dominated by concerns about one kind of firm. This suggests treating with caution a merger between the OCC and a new federal insurance regulator, or at least designing any merger to minimize the favoritism problem.

On the international front, U.S. insurance companies face difficulties in entering foreign markets, whose regulators may not be satisfied that supervision by state regulators is sufficient or may block entry to their markets in retaliation against the burdensome U.S.

\footnotetext{
${ }^{34}$ Danielle F. Waterfield, Insurers Jump on Train for Federal Insurance Regulation: Is It Really What They Want or Need? 9. CONN. INS. L.J. 283, 298 (2002-2003).
} 
state regulatory system, which they see as a barrier to entry to the U.S. market. ${ }^{35} \mathrm{~A}$ federal regulator is especially necessary to deal with these international issues.

Since optional federal chartering could give insurance companies more control and influence over their regulators than purely state-based regulation, consumer groups have legitimate concerns about the federal charter option. As J. Robert Hunter, Director of Insurance at the Consumer Federation of America, explained before the U.S. Senate in a 2003 hearing, "Consumer organizations strongly oppose an optional federal charter, where the regulated, at its sole discretion, gets to pick its regulator. This is a prescription for regulatory arbitrage that can only undermine needed consumer protections. ${ }^{, 36}$ Accordingly, there should be institutional mechanisms to make sure that consumer interests are well-represented and attended to by the federal regulator.

Finally, federal regulation should be careful to preserve an effective guaranty system, a matter discussed at more length below. Commentators have consistently identified state guaranty funds as one of the more effective elements of state insurance regulation.

\section{External Organization}

With these considerations in mind, we turn to options for how to design a federal insurance regulator to fit within the federal regulatory structure. Certain key issues must be considered.

\footnotetext{
${ }^{35}$ Peter J. Wallison, Competitive Equity: An Optional Federal Charter for Insurance Companies, American Enterprise Institute Financial Outlook (March 2006) 4.

${ }^{36}$ Statement of J. Robert Hunter Before the Committee on Commerce, Science \& Transportation of the U.S. Senate (October 22, 2003) 2. See also, Wallison, Competitive Equity, supra note 35, at 4 (further stating that "[c]onsumer advocates are...concerned that consumer interests may receive less attention at the federal level than at the state level").
} 
Independence: Some regulatory agencies, such as the Federal Reserve Board, are independent of the President. Others, such as the OCC, are instead housed within a cabinet department (Treasury, in the OCC's case, albeit with significant insulation from the Secretary of the Treasury). The greater the independence of the regulator, the less exposure it has to political pressure, but this also causes greater difficulty in coordinating policy among different regulators, short of regulatory consolidation in one independent agency. For example, the UK's Financial Services Authority (FSA) is an independent, consolidated agency encompassing the regulation of accounting, asset management, banking, securities, insurance, and other segments of the financial services industry, with separate "sector leaders" for each ${ }^{37}$ It operates as a separate agency financed by the financial services industry, with a Board selected by the UK Treasury. ${ }^{38}$

Chief official(s): What should be the characteristics of the insurance regulator's chief official? Chief officials (and, by implication, agencies themselves) may operate with different degrees of insulation from the President. The most insulated model would involve a multimember chief official body, with characteristics such as staggered terms, bipartisan composition, and "for-cause" removal. The SEC and Federal Reserve Board are examples. Next, the agency might have one chief official with some sort of "forcause" removal. An example here is the Social Security Administration. Finally, the agency might have one chief official, who serves at the pleasure of the President. An example here is the Office of the Comptroller of the Currency.

Legislative jurisdiction: Every federal regulator is overseen by particular Congressional committees. For instance, the OCC and SEC report to the Senate

\footnotetext{
${ }^{37}$ See http://www.fsa.gov.uk/Pages/About/Who/Management/Leaders/index.shtml

${ }^{38}$ See http://www.fsa.gov.uk/Pages/About/Who/index.shtml
} 
Committee on Banking, Housing, and Urban Affairs, whereas the Federal Trade

Commission reports to the Senate Committee on Commerce, Science, and

Transportation. Which Congressional committee should have jurisdiction over a federal insurance regulator?

Ad-hoc oversight: Quite separate from questions of oversight resulting from Congressional committee jurisdiction, and formal organizational relationship with the President, and consolidation with other agencies, a federal insurance regulator may also be overseen by more ad-hoc institutions composed of various executive officials. Perhaps the most relevant group for an insurance regulator is the President's Working Group on Financial Markets, which currently counts the Treasury Secretary, Chairman of the Fed, Chairman of the SEC, and Chairman of the CFTC as members.

Funding: Some regulators, such as the SEC, receive substantial amounts of their funding from congressional appropriations. Others, such as the FDIC and the OCC, receive no appropriations and are entirely funded by premiums, assessments, other fees, and earnings on investments. Reliance upon appropriations increases accountability to Congress, but at the cost of some political independence.

\section{Lessons from State Insurance Regulation}

In considering what a federal regulator might look like, it is useful to look at how state insurance regulators are organized and funded. The typical state insurance regulator is constituted as an autonomous agency, formally part of the executive branch, with one chief official appointed by the governor. An example of this paradigm is New York, where the New York State Insurance Department is headed by a Superintendent, appointed by the Governor. No state insurance regulator appears to operate under a 
multimember commission. Within state legislatures, the three most common options for committee jurisdiction over insurance regulation are either a committee on banking and financial regulation (21 states), commerce or consumer protection (12 states), or insurance specifically (11 states). A minority of states has an elected chief official for insurance, and these states often grant more formal independence from the executive to the insurance regulator. Delaware is one such state, with an elected Insurance Commissioner, subject only to removal for "reasonable cause." 39 This structure cannot, obviously, be replicated within the federal administrative structure. In and of itself, this means that a federal regulator will be less responsive to popular political pressure.

Another minority of states brings insurance regulation within another executive department, which is usually devoted either to commerce and consumer affairs or to banking and other financial services. Most of these states go further by consolidating regulation within this department, such that the insurance regulator merely is a division of a larger regulator, akin to the UK's FSA. ${ }^{40}$ An example of this is Michigan, where insurance regulation is one of the functions of the Office of Financial and Insurance Services, which also oversees banking and securities. This Office is itself a part of the Department of Labor and Economic Growth.

Oversight by an ad-hoc authority is rare. The only significant example might be Florida, where the commissioner of the Office of Insurance Regulation is appointed and overseen by the Financial Services Commission. The Financial Services Commission is

\footnotetext{
${ }^{39}$ See, 18 Del. C. $\S \S 301 \& 303$.

${ }^{40}$ Sixteen states have consolidated financial supervision for insurance, banking and securities; twelve states have consolidated supervision for banking and securities; one state (New Jersey) has consolidated supervision for banking and insurance, one state (Tennessee) has consolidated supervision for insurance and securities; twenty two states have separate supervision for all three sectors. See, Elizabeth F. Brown, E Pluribus Unum - Out of Many, One: Why the United States Needs a Single Financial Services Agency, 14 U. MiAmi Bus. L. ReV. 1, 22 (2005).
} 
composed of the Governor and cabinet. The Commission also appoints and oversees the head of the Office of Financial Regulation, which oversees banking and securities. Both the Office of Insurance Regulation and the Office of Financial Regulation are within the larger Department of Financial Services, which also has regulatory jurisdiction over Florida's state accounting and auditing, state funds, and worker's compensation.

State insurance departments may be funded from a variety of sources, including premium taxes, fees and assessments, appropriations, and penalties. ${ }^{41}$ There is considerable diversity among the several states. In California, the Department of Insurance collects fees for licensing and examination of insurance companies and agents, and deposits them into a dedicated fund; fines and penalties are deposited into the state's general fund. In Maine, the Bureau of Insurance gathers operating revenue by making an annual assessment against all licensed insurers in proportion to each company's direct gross premium. In Nevada, the legislature appropriates monies for the Department of Insurance from the general fund. The most common approach gives the state insurance department considerable freedom to collect fees for service, allowing for a degree of independence and self-funding.

\section{Conclusions About the External Structure of a Federal Insurance Regulator}

Some characteristics of state regulation are so prevalent that they may seem to be presumptively worthy of replication at the federal level. First, multimember insurance commissions are entirely absent among the states, which suggests that a Federal Reserve or SEC approach would not be appropriate at the federal level. However, state insurance regulators are often not independent from the political process, perhaps because some of the consumer issues they deal with are so highly political. Multimember setups may be

\footnotetext{
${ }^{41}$ Brady, et al., The RegUlation OF InSURANCE, supra note 25, at 89-91.
} 
more appropriate for independent regulators, to assure that the independent agency has political balance — a substitute for more active political control. Second, the latitude given to state insurance departments in the setting and collecting of fees suggests that a national insurance regulator should be self-funding, at least in part. Self-funding would allow the regulator a degree of independence from the political process, akin to that enjoyed by the Office of the Comptroller of the Currency. However, the creation of another independent federal agency with its own wellspring of funds may not be a desirable result.

In my view, it would be a mistake to create an independent agency to regulate insurance, however one decides what insurance lines may be optionally regulated at the federal level. This would further fragment federal regulation, a step in the wrong direction. However, it would also not be wise to merge the insurance and banking regulators because banking considerations are likely to be dominant, given our history and the public concern with systemic risk. Insurance would be a poor step child. ${ }^{42}$ The best approach would be to create a separate insurance regulator but use that occasion to strengthen the operational powers and resources of the President's Working Group on Financial Markets, which currently includes the Treasury, the Federal Reserve, the SEC and the CFTC, over all the federal regulators

Consolidated regulation could increase efficiency and allow coordination between insurance regulators and other financial regulators. This coordination is important for ensuring fair competition between insurance and other financial institutions. It is also

\footnotetext{
${ }^{42}$ Jack Chesson of NAIC remarks: "The bank regulators would not be suitable... as we know from the savings and loan experience, the regulators had no trouble subordinating regulation and disclosure to their primary function of protecting the banks." Chesson, The Views of the National Association of Insurance Commissioners, Optional Federal Chartering AND REgUlation of InSURANCE COMPANIES, ed. Peter J. Wallison (2000) 74.
} 
important in dealing with foreign states as it ensures a unified voice for U.S. regulation and allows for a more rapid response to changing international events. Other virtues of consolidated regulation may include better handling of issues unique to financial conglomerates (such as conflicts of interest) ${ }^{43}$ greater resistance to capture by a particular sector in financial services, ${ }^{44}$ and reduced confusion for consumers seeking information or to file a complaint. ${ }^{45}$ On the other hand, a consolidated regulator might become large and unwieldy ${ }^{46}$ and unresponsive to the needs of small firms. ${ }^{47}$

\section{Internal Structure}

The internal structure of the federal chartering agency must be determined in large part by the lines of insurance to be governed by a federal charter. This section considers the issues posed for the internal structure of the federal chartering agency by three lines of insurance: life, and two lines of property and casualty insurance, individual passenger automobile ("auto"), and commercial general liability ("commercial").

No state has a distinct set of rules for each insurance line, nor would such regulatory tailoring be sensible given the existence of common issues across lines and the fact that few remaining insurers are "monoline" companies. The fact that multiline insurers currently face common regulation of lines in the states strongly suggests that an optional federal chartering system that splits regulation of lines between the federal government and the states will increase the cost of regulation rather than decreasing it.

\footnotetext{
${ }^{43}$ Brown, E Pluribus Unum - Out of Many, One, supra note 40, at 38-46.

${ }^{44} I d$., at $50-52$.

${ }^{45} \mathrm{Id}$., at 59 .

${ }^{46}$ Id., at $94-96$.

${ }^{47}$ Id., at 97.
} 
To avoid this result, a federal option should provide that insurance firms have the choice of being regulated at the federal level for solvency and other forms of regulation that do not vary by line. Even if state solvency regulation currently varies by line, e.g. requiring more capital for more risky insurance products, the federal government should still regulate all insurance products for solvency. Thus, even if product regulation for firms choosing a federal charter were to be split between the states and the federal government, all firm regulation would take place only at the state or federal level.

As Table I shows, state regulators have taken different approaches to the regulation of life, individual auto and commercial insurance. 
Table I: Overview of State Regulation of Life, Auto and Commercial Insurance

\begin{tabular}{|c|c|c|c|}
\hline $\begin{array}{l}\text { Regulatory } \\
\text { Functions }\end{array}$ & Life & Auto & Commercial \\
\hline $\begin{array}{l}\text { Chartering \& } \\
\text { Licensing }\end{array}$ & $\begin{array}{l}\text { State-by-state } \\
\text { - Capital \& surplus } \\
\text { requirements } \\
\text { - Revocation w/ } \\
\text { notice \& hearing }\end{array}$ & \begin{tabular}{|l} 
State-by-state \\
- Capital \& \\
surplus \\
requirements \\
- Revocation w/ \\
notice \& hearing \\
\end{tabular} & $\begin{array}{l}\text { State-by-state } \\
\text { - } \text { Capital \& surplus } \\
\text { requirements } \\
\text { - Revocation w/ notice \& } \\
\text { hearing }\end{array}$ \\
\hline Financial Reporting & $\begin{array}{l}\text { Annual } \\
\text { - Certified } \\
\text { - Audited financial } \\
\text { statements } \\
\text { Quarterly }\end{array}$ & $\begin{array}{l}\text { Annual } \\
\text { - Certified } \\
\text { - Audited } \\
\text { financial } \\
\text { statements } \\
\text { Quarterly }\end{array}$ & $\begin{array}{l}\text { Annual } \\
\text { - Certified } \\
\text { - Audited financial } \\
\text { statements } \\
\text { Quarterly }\end{array}$ \\
\hline Financial Examination & $\begin{array}{l}\leq 3-5 \text { years } \\
\text { "Zone System" }\end{array}$ & $\begin{array}{l}\leq 3-5 \text { years } \\
\text { "Zone System" }\end{array}$ & $\begin{array}{l}\leq 3-5 \text { years } \\
\text { "Zone System" }\end{array}$ \\
\hline $\begin{array}{l}\text { Policy Form } \\
\text { Regulation } \\
\end{array}$ & $\begin{array}{l}\text { Prior approval (PA) } \\
\text { in most states } \\
\end{array}$ & PA in most states & PA in most states \\
\hline Rate Regulation & $\begin{array}{l}\text { Generally "file and } \\
\text { use" (FU) or "use } \\
\text { and file" (UF). } \\
\text { Some no filing (NF) }\end{array}$ & $\begin{array}{l}\text { PA in most states. } \\
\text { Some FU or UF. }\end{array}$ & $\begin{array}{l}\text { Mixed. } \\
\text { Some states require PA. } \\
\text { Most FU or UF. } \\
\text { Few NF. }\end{array}$ \\
\hline $\begin{array}{l}\text { Residual Risk } \\
\text { Mechanism }\end{array}$ & No. & $\begin{array}{l}\text { Yes. Many states } \\
\text { have universal } \\
\text { coverage or no- } \\
\text { fault. }\end{array}$ & No. \\
\hline $\begin{array}{l}\text { Market Conduct } \\
\text { Regulation/Examination }\end{array}$ & Yes. & $\begin{array}{l}\text { Yes. Highest } \\
\text { level of scrutiny. }\end{array}$ & $\begin{array}{l}\text { Yes. Lower level of } \\
\text { scrutiny. }\end{array}$ \\
\hline Consumer Services & $\begin{array}{l}\text { Yes. } \\
\text { - Brochures /guides } \\
\text { - Complaints / } \\
\text { inquiries }\end{array}$ & $\begin{array}{l}\text { Yes. } \\
\text { - Brochures } \\
\text { /guides } \\
\text { - Complaints / } \\
\text { inquiries } \\
\end{array}$ & $\begin{array}{l}\text { Yes. } \\
\text { - Guides for certain lines } \\
\text { (e.g., medical } \\
\text { malpractice \& } \\
\text { workers' comp.) }\end{array}$ \\
\hline Fraud Investigation & $\begin{array}{l}\text { Most states have } \\
\text { distinct insurance } \\
\text { fraud bureaus. Nine } \\
\text { states rely upon } \\
\text { police and } \\
\text { prosecutors. }\end{array}$ & $\begin{array}{l}\text { Most states have } \\
\text { distinct insurance } \\
\text { fraud bureaus. } \\
\text { Nine states rely } \\
\text { upon police and } \\
\text { prosecutors. }\end{array}$ & $\begin{array}{l}\text { Most states have distinct } \\
\text { insurance fraud bureaus. } \\
\text { Nine states rely upon } \\
\text { police and prosecutors. }\end{array}$ \\
\hline
\end{tabular}




\section{Life Insurance}

Life insurance companies offer life insurance contracts and other financial products (e.g., annuities) to retail customers, businesses, and groups. The market for life insurance products is highly competitive, a situation enhanced by increasing competition from banking and securities products. As industry executives and observers note, this is not simply a matter of banks offering life insurance in the wake of the Gramm-Leach-Bliley Act, but of a more fundamental convergence taking place in the financial services industry. Life insurance companies have been among those most interested in a federal chartering option.

Solvency Regulation. Life insurers are subject to solvency regulation in each of the states and territories in which they do business. Solvency regulation encompasses chartering and licensing, and involves periodic financial reporting and examination requirements. As a rule, an insurer must be chartered as either a life insurance company or a property/casualty company, and will be licensed to issue one or more lines within these broad categories. ${ }^{48}$ In order to be chartered and licensed, insurers must meet minimum capital and surplus requirements, which vary by category and line. Considerable uniformity already has been imposed upon states' minimum capital and surplus requirements by their adoption of Risk Based Capital Model Acts promulgated by the National Association of Insurance Commissioners (NAIC). However, a few states, including New York, have retained their own fixed minimum capital and surplus requirements. A multistate, multiline insurer generally must meet the greater of NAIC's minimum riskbased capital requirements or the minimum capital requirements of each state in which it is licensed to do business. ${ }^{49}$ In addition to minimum capital requirements, states regulate market entry through "seasoning"

\footnotetext{
${ }^{48}$ The separation between life and property/casualty insurers seems to be the historical legacy of "monoline" insurance regulation, which began with the New York legislature's 1849 decision to require each insurance company to issue only a single line. Insurers began offering multiple lines during the early twentieth century; however, legislation providing for the licensing of multiline insurers was not adopted by the states until after 1945. See Brady, et al., The Regulation of InSURANCE, supra note 25, at 36-40. ${ }^{49}$ Minimum capital requirements vary by line, and by state. During the 1990 s, the National Association of Insurance Commissioners (NAIC) sought to harmonize state regulation by adopting model minimum riskbased capital (RBC) requirements for most lines (including life and property/casualty). States seeking NAIC accreditation were required to adopt these RBC model acts. Thus, in a NAIC-accredited state, an insurer's minimum capital requirement would vary according to the lines offered, which pose different risks. In a non-NAIC accredited state, an insurer may be subject to fixed minimum capital and surplus requirements for each line that an insurer may seek to offer. An insurer seeking to offer multiple lines would be required to meet an aggregate minimum, or a distinct multiline minimum. See, e.g., N.Y. Ins. L. $\S 4103$; see also, Kathleen Heald Ettlinger, et al., State InSURANCE REgUlAtion (1995) 15-19. A
} 
and other requirements. After becoming licensed, both life and property/casualty insurers must file annual and quarterly financial reports, and submit to periodic "full-scope" and occasional "targeted" financial examinations.

Because the underwriting risks faced by life insurers are distinct (see, e.g., the long time frame of life insurance contracts), state regulators have subjected these companies to tougher chartering/licensing requirements and accounting standards than those applied either to property/casualty insurers or banks. For example, life insurers are subject to special investment restrictions and accounting for their policy reserves.

Many states already base their financial reporting requirements upon universal standards prescribed by NAIC and accept "zone examinations" of multi-state insurers; therefore, insurers and the federal regulatory system will reap only limited cost savings from a single federal reporting and examination system. ${ }^{50}$ However, federal regulatory oversight of insurer solvency could further enhance the efficiency of the insurance industry. First, a federal regulator could abolish the traditional division of insolvency regulation between life and property/casualty insurance. While these types of insurance face distinct risks, so do the different individual sublines of property/casualty insurance, which nevertheless may be offered by a single insurer. ${ }^{51}$ Following state regulators' shift to a risk-based capital model, the federal regulator may contemplate chartering

multistate, multiline insurer generally must meet the greater of its minimum RBC requirements or the minimum capital requirements of each state in which it is licensed to do business. There is no reason that a federal regulator could not promulgate solvency regulations that would be equally sensitive to the different risks posed by different product lines - and more uniform.

${ }^{50}$ The federal regulator may reduce costs by conducting financial examination on an as-needed or prioritized basis (i.e., in response to a complaint or law-breaking), rather than a strictly periodic basis. NIA would require the Commissioner to conduct an on-site examination of each federally chartered insurance company at least once every three years; however, insurance agencies would be subject to examination only in response to a complaint or law-breaking. See, NIA $\S 1125$.

${ }^{51}$ See, e.g., N.Y. Ins. L. $§ \S 4101-4102$. 
consolidated federal insurance companies authorized to do business in any line of insurance, provided it has adequate risk-adjusted capital and surplus. ${ }^{52}$

Second, a federal regulator could consider either the elimination of capital/surplus requirements for life insurance companies, or a convergence with banking capital requirements and accounting standards. To the extent that the capital requirements of life insurers are more conservative than those of banks and securities firms offering similar products, insurers will be at a competitive disadvantage. Insurers are required to file financial reports in keeping with statutory accounting principles (SAP) rather than generally accepted accounting principles (GAAP). SAP differs from GAAP in terms of the valuation, realization, and continuity issues imposed on reporting companies (e.g., SAP generally takes a liquidation rather than going concern perspective). Use of the same accounting treatment for insurance products by both insurance companies and banks could eliminate artificial inconsistencies and competitive advantages..

Rate/Policy Form Regulation and Consumer Protection. Life insurance rates generally are lightly regulated or unregulated by the states. However, this light touch is significantly offset by requirements in most states that policy forms be subject to prior approval of the state insurance department. Thus, in order to introduce a new product, a life insurer must seek the approval of the insurance regulator in each state in which it does business. Life insurers also are subject to state market conduct regulation and examination (e.g., advertising restrictions).

Life insurers report significant direct and indirect costs arising from this contradictory and fragmented mélange of state regulation. ${ }^{53}$ For example, life insurers

\footnotetext{
${ }^{52}$ The current proposal would not allow a National Insurer to hold licenses for both life and property/casualty insurance. See, NIA $\S 1203$.
} 
may have to create different versions of products tailored to the policy forms of particular states, and employ multiple state-based compliance staffs. This puts life insurers at a competitive disadvantage vis-à-vis banks and securities firms.

Unification of the regulation of rates and policy forms in a single federal regulator obviously would reduce compliance costs to life insurers; elimination of prior approval of rates and policy forms would be of further value, enabling life insurers to compete with banks and securities firms on a more even playing field. ${ }^{54}$ Because the market for life insurance products is highly competitive, consumer protection should take the form of simple regulations regarding market conduct, along with obligations to inform retail consumers.

Conclusion. Full optional federal chartering of life insurance, safety and soundness and product regulation seems to create more opportunities than challenges. State product regulation of life insurance is mainly concerned with policy form issues, given the competitive nature of pricing in this market. If the federal charter also encompassed the regulation of the solvency of property/casualty insurers (see discussion below), the federal regulator could consolidate its regulation of these two lines.

An important internal structure issue raised by the need to protect life insurance consumers is whether the consumer protection function should be separated from the solvency regulation function-i.e., into two separate Divisions, a Division of Financial Services and a Division of Consumer Protection. Most state regulators have a separate bureau of consumer affairs, and one is contemplated by the NIA. To the extent that

\footnotetext{
${ }^{53}$ ACLI, ECONOMIC IMPACT OF AN OPTIONAL FEDERAL CHARTER ON THE LIFE INSURANCE INDUSTRY (Aug. 2005).

${ }^{54}$ As noted above, the NIA would establish a "file and use" system for life insurance policy forms, and allow the Commissioner to exempt particular categories from the filing requirement. Life insurers would be allowed to classify policyholders and set rates freely. NIA $\S 1213$.
} 
market regulation/examination and consumer education/complaints may be "scaled" across lines, e.g. the federal regulator deals with consumer issues in multiple lines, a single bureau of consumer affairs will be desirable.

Another issue is whether the enforcement function should be separated from the supervisory function — as, for example in the SEC, which has a separate Division of Enforcement. The Office of the Comptroller of the Currency is an example of a more integrated approach: primary responsibility for enforcement is allocated by "line" to the senior deputy comptrollers for Bank Supervision Operations for Community/Mid-Size Banks and for Large Banks. The difference between the SEC and OCC is a product of the agencies' distinct "regulatory styles": The SEC seeks to protect investors on a transactional basis; OCC endeavors to align the market conduct of banks on a broader supervisory basis. The Committee on Capital Market Regulation has suggested that the SEC move to a more prudential approach to regulation, only using enforcement if the prudential approach fails. ${ }^{55}$ This approach counsels against creating a separate enforcement division in insurance.

Commercial Insurance

Property/casualty companies offer commercial general liability insurance to businesses, often along with other lines like commercial auto and workers' compensation insurance. The market for commercial insurance is highly competitive, and purchasers of commercial insurance generally are large and informed.

Solvency Regulation. Like life insurers, commercial property/casualty insurers are subject to minimum capital and surplus requirements for chartering and licensing, as

\footnotetext{
${ }^{55}$ INTERIM REPORT OF THE COMMITTEE ON CAPITAL MARKETS REGULATION (November 30, 2006) 9 \& 6667.
} 
well as periodic financial reporting and examination by state insurance regulators. The rationale for these requirements obviously is to ensure the solvency of insurers who have promised to deliver future contingent benefits to policyholders or their beneficiaries. A federal insurance regulator could lower regulatory costs and enhance competition through more uniform and consistent chartering, licensing, and financial reporting requirements.

Insofar as their products are sold in competitive markets to presumptively sophisticated buyers, a federal insurance regulator might decide to eliminate capital and surplus requirements altogether for commercial insurers. Commercial insurers face increased competition from the growing market in alternative risk transfer mechanisms, such as credit derivatives. To the extent that suppliers of alternative risk transfer products are subject to lower (or no) capital requirements, prices and consumer choice may be distorted in the market for commercial lines. Minimum capital and surplus requirements also hamper the entry of new commercial insurers whose products might find willing, sophisticated buyers. On the other hand, financial reporting and examination may be justified insofar as it reduces the risk of insolvency by eliminating duplicative diligence costs that would otherwise have to be undertaken by customers, albeit sophisticated ones.

Rate/Policy Form Regulation and Consumer Protection. Like life insurance, commercial insurance enjoys de facto rate deregulation, but (rather surprisingly) remains subject to considerable policy form regulation. ${ }^{56}$ Prior approval of policy forms increases commercial insurers' time-to-market, disadvantaging them vis-à-vis firms offering

\footnotetext{
${ }^{56}$ Richard J. Butler, Form Regulation in Commercial Insurance, DEREGUlATING PROPERTY LiABILITY INSURANCE: RESTORING COMPETITION AND INCREASING MARKET EFFICIENCY, ed. J. David Cummins (2001) 321 .
} 
alternative risk transfer products. It is not clear what purpose prior approval of policy forms serves when rates are deregulated and purchasers are sophisticated. ${ }^{57}$

Other than fraud investigation, consumer protection issues are not implicated by commercial general liability insurance.

Conclusion. As with life insurance, full optional federal chartering of commercial insurance, safety and soundness and product regulation, seems to create a number of opportunities to reduce regulatory costs and enhance product market efficiency. Commercial insurance generally poses few consumer protection problems. However, workers compensation insurance, which operates in a distinct market and regulatory environment, ${ }^{58}$ may be offered by commercial general liability insurers in most states. ${ }^{59}$ This raises a serious question for those who would limit federal chartering of insurance only to life and/or "commercial" insurance: ${ }^{60}$ Will a national commercial insurer be limited to commercial general liability insurance alone? Such limited licensing would require a "full service" national commercial insurer to be simultaneously chartered in workers' compensation in each state in which it seeks to do business.

\section{Auto Insurance}

Property/casualty insurers also offer voluntary auto insurance to retail consumers in strictly regulated markets. Universal coverage often is mandated or encouraged by regulators, and is provided by

\footnotetext{
${ }^{57}$ As noted above, the NIA would establish a "use and file" system for property/casualty insurers, and would prohibit the Commissioner from requiring property/casualty insurers to use "any particular rate, rating element, price, or form." NIA § 1214.

${ }^{58}$ Workers compensation rates and forms are strictly regulated; indeed, a few states retain monopoly state workers' compensation funds.

${ }^{59}$ See, e.g., N.Y. Ins. L. § 4102(b)(1).

${ }^{60}$ Ernest T. Patrikis, Optional Federal Chartering for Property and Casualty Companies, OPTIONAL FEDERAL CHARTERING AND REgULATION OF InSURANCE COMPANIES, supra note 42, at 47-51 (advocating federal chartering for commercial property/casualty). Recently, House Financial Services Capital Markets Subcommittee Chairman Rep. Paul Kanjorski has said that optional federal chartering should be available only for life insurance. See, Bill Swindell, Kanjorski Backs Federal Regulator; Insurance Groups Split, CONGRESS DAILY (Feb. 8, 2007).
} 
residual risk mechanisms such as assigned risk pools. Consumer groups have objected to the extension of federal chartering to auto insurance and other retail property/casualty insurance on the grounds that the federal regulator would be unable or unwilling to provide adequate consumer protection.

Solvency Regulation. Retail auto insurance, like other lines, is subject to minimum capital and surplus requirements for chartering and licensing, and periodic financial reporting and examination by state insurance regulators. The rationale for such supervision is the necessity to protect consumers with limited information and monitoring capacity from unscrupulous "fly-by-night" insurers. The basic contours of federal solvency regulation and its benefits are substantially the same as those discussed for life insurance.

Rate/Policy Form Regulation and Consumer Protection. Auto insurance regulation touches all aspects of consumer protection, including rates and policy forms, market conduct, and consumer education and complaints. The consumer protection concern is stronger for auto than life in large part because auto insurance is mandatory for drivers, i.e. most people, whereas, life insurance is optional.

Generally, auto insurance rates and policy forms are strictly regulated; for example, Massachusetts sets uniform rates and rating classes for insurance companies, and requires prior approval of policy forms. However, rate and policy form regulation differs greatly between states. Even two "prior approval" states may impose different burdens upon insurers, depending upon the stringency and speed of review, as well as the use of such regulation to suppress rates. ${ }^{61}$ State regulators are strict in enforcing market conduct regulation and swift in responding to consumer complaints.

\footnotetext{
${ }^{61}$ See, Scott Harrington, InsUrance Deregulation AND the Public InTERest (2000) 11-14.
} 
The variety of state rate and policy form regulation imposes considerable direct and indirect costs upon auto insurers and results in various cross-subsidies between consumers with different risk profiles. Even if a federal regulator required prior approval of rates and/or policy forms, regulatory costs would be lowered by the adoption of a uniform approach. However, because the market for voluntary auto insurance in most states is highly competitive, a federal regulator may choose to deregulate rates and/or policy forms. ${ }^{62}$ Illinois has completely deregulated rates for voluntary auto insurance since 1971 (it still regulates insolvency, market conduct, etc.). Observers report that auto insurance is widely available and rates are competitive in Illinois; moreover, deregulation seems to have had no adverse effect upon loss ratios, the size of the uninsured and residual market, or insurer solvency ${ }^{63}$ Consumer protection in a deregulated rate environment may be buttressed by the elimination of the federal antitrust exemption for national insurers (to prevent rate collusion). ${ }^{64}$

Even in a competitive, rate deregulated national auto insurance market, the federal insurance regulator may desire to regulate market conduct for the protection of consumers. Such an initiative may require a distinct division of market conduct and consumer protection dedicated to retail policyholders and beneficiaries. The more lines that can be regulated at the federal level that raise such consumer concerns, the more justification there would be for a separate division.

Residual Risk Mechanism. In order to guarantee the availability of auto insurance, every state has a residual risk market or assigned risk pool for drivers unable to secure voluntary auto insurance. Auto insurers doing business in a state participate in its residual risk market on a pro rata basis. State workers compensation insurance generally has a similar mechanism. The NIA would not create a national residual

\footnotetext{
${ }^{62}$ For all property casualty insurance, including auto insurance, the NIA would establish a "use and file" system, and would prohibit federal rate regulation. See, NIA § 1214.

${ }^{63}$ Stephen P. D'Arcy, Insurance Price Deregulation: The Illinois Experience, DeREgUlating ProPerTy LIABILITY INSURANCE: RESTORING COMPETITION AND INCREASING MARKET EFFICIENCY, supra note 56, at 281-282.

${ }^{64}$ California's Proposition 103 did this at a state level.
} 
risk mechanism. ${ }^{65}$ Federally chartered insurers would remain subject to applicable state law relating to participation in assigned risk pools. ${ }^{66}$

If national auto insurers are required to participate in state residual risk markets, regulatory supervision will be divided between federal (solvency and consumer protection) and state (residual risk compliance). This may raise direct compliance costs to insurers, as well as indirect costs related to increased time to market for new products.

There are two other options: the creation of a national residual risk mechanism, or the preemption of state residual risk mechanisms without the creation of a new one (a very unlikely alternative, politically). Obviously, the existence of a national residual risk mechanism would require national administration of a regulatory function unique to this kind of insurance. But national pooling offers the advantage of spreading the costs of underwriting losses among all insurers on a national basis.

Conclusion. Auto insurance is distinct in two respects: it raises consumer protection issues different (and greater) than those raised by life and commercial insurance; and, it poses distinct problems of residual risk mechanisms. The distinct nature of auto (and other retail property/casualty) insurance may offer some support to those who would restrict optional federal chartering to life and/or commercial lines. But the potential regulatory and market efficiencies achievable by a universal federal chartering option (of all firms and lines) may outweigh these concerns.

Table II presents the major issues raised in the design of the federal chartering agency's internal structure. As is clear from the table, there is considerable harmony across lines in terms of solvency regulation. This is not surprising, given the fact that

\footnotetext{
${ }^{65}$ NIA $\$ 1214$.

${ }^{66}$ NIA $\S 1125(\mathrm{~b})(3)$. However, as noted above, no state may require a national insurer to participate in any residual risk mechanism that "fail[s] to cover the expected value of all future costs" associated with it, providing a meaningful protection for national insurers.
} 
solvency is a firm-based, rather than product-based, phenomenon, and given the trend toward convergence across product lines. As is equally clear, the major differences between lines arise in the area of consumer protective regulation. Neither life nor commercial insurance requires great market conduct regulation or examination, given the relative simplicity of these products and the competitiveness of the markets for them. The ultimate question then, is whether and how the whole or partial integration of auto (and other retail property/casualty) insurance may be effected. 
Table II: Issues Raised in Internal Design of OFC

\begin{tabular}{|c|c|c|c|}
\hline $\begin{array}{l}\text { Regulatory } \\
\text { Depts. \& Functions }\end{array}$ & Life & Auto & Commercial \\
\hline $\begin{array}{l}\text { Chartering \& } \\
\text { Licensing }\end{array}$ & \multicolumn{3}{|c|}{$\begin{array}{l}\text { - Consolidated chartering and licensing } \\
\text { - Consolidated capital/surplus requirements }\end{array}$} \\
\hline Financial Reporting & \multicolumn{3}{|c|}{$\begin{array}{l}\text { - Consolidated or separate reporting } \\
\text { - Reconciliation of SAP \& GAAP? }\end{array}$} \\
\hline Financial Examination & \multicolumn{3}{|c|}{$\begin{array}{l}\text { - Consolidated regulator to oversee banking \& insurance exam? } \\
\text { - As-needed/prioritized examination? }\end{array}$} \\
\hline $\begin{array}{l}\text { Policy Form } \\
\text { Regulation } \\
\text { (Competition) }\end{array}$ & Competition: Banks & $\begin{array}{l}\text { Currently no } \\
\text { competitive threat } \\
\text { from non-insurance } \\
\text { financial services }\end{array}$ & $\begin{array}{l}\text { Competition: } \\
\text { Self-insurance, } \\
\text { alternative risk } \\
\text { transfer } \\
\text { products }\end{array}$ \\
\hline $\begin{array}{l}\text { Policy Form Regulation } \\
\text { (Consumer Protection) }\end{array}$ & $\begin{array}{l}\text { Informative prices } \\
\text { Two consumers: retail \& } \\
\text { wholesale (business, } \\
\text { group) }\end{array}$ & $\begin{array}{l}\text { Consumer protection } \\
\text { - Complexity } \\
\text { - Fair v. unfair } \\
\text { discrimination }\end{array}$ & $\begin{array}{l}\text { Informed, } \\
\text { sophisticated } \\
\text { buyers }\end{array}$ \\
\hline Rate Regulation & $\begin{array}{l}\text { Competitive mkt } \\
\text { Voluntary }\end{array}$ & $\begin{array}{l}\text { Competitive mkt } \\
\text { Often required/ deemed } \\
\text { socially desirable }\end{array}$ & $\begin{array}{l}\text { Competitive mkt } \\
\text { Voluntary }\end{array}$ \\
\hline $\begin{array}{l}\text { Residual Risk } \\
\text { Mechanism }\end{array}$ & No & $\begin{array}{l}\text { Options: } \\
\text { - Participation in state } \\
\text { pool } \\
\text { - Creation of national } \\
\text { pool } \\
\text { - No national pool }\end{array}$ & No \\
\hline $\begin{array}{l}\text { Market Conduct } \\
\text { Regulation/Examination }\end{array}$ & $\begin{array}{l}\text { Unfair competition } \\
\\
\text { Deceptive Conduct } \\
\text { - Informative prices } \\
\text { - Regulatory Style: } \\
\text { Disclosure v. } \\
\text { Prescription }\end{array}$ & $\begin{array}{l}\text { Unfair competition } \\
\text { Deceptive Conduct } \\
\text { - Complexity }\end{array}$ & Unfair competition \\
\hline Consumer Services & $\begin{array}{l}\text { Education } \\
\text { Complaints }\end{array}$ & $\begin{array}{l}\text { Education } \\
\text { Complaints }\end{array}$ & Complaints \\
\hline Fraud Investigation & Separ: & fraud bureau? & \\
\hline
\end{tabular}




\section{Guaranty Funds}

The state guaranty fund system is an important facet of insurance regulation that has been a cause of concern for federal chartering. These funds are in place to compensate for the losses suffered by third parties and policyholders due to insurance company insolvency. Since insurance regulators are responsible for preventing this insolvency, guaranty funds may be framed as a sort of "product warranty" for the quality of regulation. ${ }^{67}$ The general perception is that the administration of state guaranty funds has been one of the most effective components of state insurance regulation.

States, at the behest of insurance companies, began to create these funds starting in 1969, perhaps in response to pressure for federal regulation. The first wave of funds provided protection for life and health insurers, with subsequent waves spreading coverage to property and casualty insurers. These product divisions remain today, and often include subdivisions, or "accounts," for particular lines of insurance. Assessments for policyholder claims against insolvent insurers are made against the appropriate "account."68 The funds typically are organized as compulsory membership nonprofit associations of all insurance companies licensed in the state. They are administered by a board composed of representatives from insurance companies and the state insurance regulator, with some states including representatives of the public as well. Much like FDIC premiums, most state guaranty assessments are not truly risk-sensitive, which has been a source of criticism. Also, some states allow insurers, especially life and health insurers, to offset the taxes they pay on premiums by the amount of guaranty fund

\footnotetext{
${ }^{67}$ Bert Ely, The Fate of the State Guaranty Funds after the Advent of Federal Insurance Chartering, OPTIONAL FEDERAL CHARTERING AND REGULATION OF INSURANCE COMPANIES, supra note 42, at 137-138. ${ }^{68}$ Ettlinger, et al., STATE InSURANCE Regulation, supra note 49, at 224-225.
} 
assessments paid. As a result, some of the cost of insolvency losses is passed along to taxpayers, who must make up for any shortfall in taxation created by these offsets.

The two most often praised features of the state guaranty fund system are its approach to assessments and level of coverage. With the exception of New York, every state fills its guaranty fund on a post-assessment basis. That means that member insurance companies do not pay into a fund until around the end of the year, and only to the extent necessary to compensate for losses. This may be contrasted with funding on a pre-assessment basis, wherein companies would pay into the fund before losses are known, as is the case with the FDIC fund for banks. Recently, the New York state legislature has taken advantage of its state's pre-assessment fund by siphoning off the fund's resources for general spending. This suggests that any prefunding mechanism needs to be highly insulated from the political process.

Additionally, state guaranty funds generally have low coverage limits. Commentators hail these limits as promoting efficient behavior by insurance companies. Due to the low limits, companies have incentives to self-insure by controlling their risk of insolvency. These incentives tend to minimize losses. Were coverage limits to be higher, insurance companies might be more likely to engage in risky behavior, such as writing more high risk policies, due to moral hazard. These are the same issues encountered in setting the appropriate level of FDIC insurance for banks.

Owing to this positive appraisal of state guaranty funds, many commentators have adopted an approach along the lines of "if it ain't broke, don't fix it." Indeed, postassessment funding and low coverage limits suggest that state guaranty funds do not 
suffer from the same weaknesses of over-regulation and inefficiency that might justify more general reform of insurance regulation.

If we operate from the perspective that state guaranty funds operate well and should continue in operation, then we should pay attention to whether optional federal chartering of insurers might impair the effectiveness of the state guaranty system. There are a few reasons to have such concern. First, federal regulators might worry about relying upon state funds in the case of insolvency. If a large national insurance company were to fail, then some state funds might have insufficient assessment capabilities to compensate for the losses of third parties and policyholders within that state's jurisdiction. Also, state funds do not exhibit a uniform level of protection, ${ }^{69}$ which means that different federally chartered insurers would have different insolvency protection, depending upon where they operate. Federal regulators might, therefore, insist upon uniform minimum standards for the operation of state guaranty funds. The insurance industry has generally supported this approach. ${ }^{70}$

On the other hand, state insurance regulators have questioned the uniform minimum standards approach. ${ }^{71}$ It could result in different standards for federally chartered and state chartered insurance companies if the federal minimum standard only applied to federally chartered insurers. More likely it would set the same federal standards for both federal and state chartered firms, thus ousting state regulators of some of their jurisdiction. However, the entire project of federal regulation with state guaranty necessitates severing the link between regulation and guaranty that is the backbone to the

\footnotetext{
69 " [C] ]overage limits vary from state to state, up to $\$ 500,000$, by type of insurance product and by type of liability (prepaid premiums versus actual loss, cash values versus life insurance death benefits, and so forth)." Ely, supra note 67, at 142.

${ }^{70}$ Harrington, supra note 9, at 19.

${ }^{71}$ Id..
} 
idea of guaranty as product warranty. This idea is premised upon the notion that regulators will act more effectively if they must bear the cost of poor regulation. This efficacy will not obtain if state funds bear the costs of poor federal regulation. It was precisely this concern that led to federal involvement in safety and soundness regulation for state chartered banks using federal deposit insurance. ${ }^{72}$

Concerns about the potentially adverse impact of federal regulation upon the state guaranty system might be grounds for installing a federal guaranty fund for federally chartered insurers. Such a fund would successfully tie federal regulation to federal guaranty, thereby satisfying the product warranty rationale. There might also be some subsidiary benefits of a federal fund. It would imply uniformity of protection for federally chartered insurers. If a diverse group of insurers choose to operate under federal charter, then there might be better pooling of risk as compared with state funds, which have a more limited geographic base from which to draw members.

Additionally, there would be no passing off of externalities from one state to another. ${ }^{73}$ Currently, state regulators have less incentive to regulate multistate insurers because other states' funds share the costs of insolvency. A federal fund would eliminate this practice for federally chartered insurers because the federal fund would not be able to pass the buck of insolvency on to other funds. On the other hand, some have argued that the possibility of externalities to insolvency actually improves state regulation because it

\footnotetext{
${ }^{72}$ See Ely, supra note 67, at 136-37.

${ }^{73}$ See Martin F. Grace \& Richard D. Phillips, The Allocation of Governmental Regulatory Authority: Federalism and the Case of Insurance Regulation, Center for Risk Management and Insurance Research No. 96-2 6, available at http://ssrn.com/abstract=146609 (1999).
} 
gives state regulators an incentive to monitor the quality of regulation in domiciliary states. $^{74}$

If legislators were to opt for a federal guaranty fund, a number of structural concerns would need to be addressed. First, as discussed earlier, most state funds have divisions and subdivisions keyed to different insurance products. The presence and extent of such divisions in a federal fund would have to be decided. Legislators would also have to consider whether state chartered insurers would be eligible for the fund, just as state chartered banks are eligible for federal deposit insurance. Also, like federal deposit insurance, there is a question as to how premiums would be assessed. Risk-based premiums seem ideal, if difficult to implement. If the federal guaranty fund is structured like federal deposit insurance, then it might even make sense for the FDIC to administer the fund. ${ }^{75}$ Additionally, there are a number of unique concerns that would arise during the transition by insurers from membership in state funds to membership in a federal fund. $^{76}$

\section{Conclusion}

There are several important issues to be considered in designing a regulatory structure for the optional federal chartering option for insurance. First and foremost, the objectives of insurance regulation and the rationale for optional federal chartering must guide regulatory design. Second, lessons learned from existing federal and state financial services regulators regarding the external structure of such an agency must be borne in

\footnotetext{
${ }^{74}$ Jonathan R. Macey \& Geoffrey P. Miller, The McCarran-Ferguson Act of 1945: Reconceiving the Federal Role in Insurance Regulation, 68 NYU L. REV. 13, 79 (1993).

${ }^{75}$ See Ely, supra note 67, at 145.

${ }^{76}$ Examples include need for exit fees to prevent exodus from state to federal regulation just before assessment due to failure of a large company and for a mechanism for dealing with insolvency of newly chartered federal companies. Lissa Broome, A Federal Charter Option for Insurance Companies: Lessons from the Bank Experience, in FinAnCial Regulation After Gramm-Leach-Bliley (Pat McCoy, ed., 2002), available at http://ssrn.com/abstract $=334440$.
} 
mind. Chief among these lessons is the disjunction between the accelerating convergence of financial services and the current fragmentation of our regulatory system. Third, the choice of the lines of insurance to be governed by a federal charter should be considered in designing the internal structure of the federal agency; at the same time, the choice of lines itself must be driven by our objectives in offering a federal option. Finally, the participation of national insurers in state residual risk mechanisms and guaranty funds must be determined, with reference to both consumer protection and efficiency goals.

While the federal government should have primacy in the regulation of insurance, it would be a mistake to establish a wholly independent Office of National Insurance (as contemplated by the NIA), further fragmenting federal regulation of financial services. Neither would it be wise to consolidate federal regulation of banking and insurance under a single agency (a point upon which both NAIC and multistate insurance companies agree). In my view, the optimal external structure would involve the establishment of a distinct insurance regulator subject to oversight by the President's Working Group on Financial Markets. This approach is most likely to provide the greatest benefits arising from optional federal chartering of insurance—cost savings from uniformity, economies of scale, and appropriate deregulation, along with the benefits of coordinated financial services regulation —at the lowest cost. It would also combine regulatory expertise and independence with strong political oversight and accountability. Finally, it might serve as a first step toward consolidated federal financial services regulation, beginning with the reconciliation of capital requirements and accounting standards for all financial services firms. 
The federal regulator of insurance should provide a true federal "option": national insurers should be subject only to federal regulation of their solvency and product offerings, and should be able to offer many lines of insurance. A federal regulator would be well situated to set and enforce appropriate risk-based capital requirements for national insurers, based upon product line and other relevant risk factors. Indeed, a federal regulator could consider removing the traditional barrier between life and property/casualty insurers, particularly in the wake of the Gramm-Leach-Bliley Act. The benefits of optional federal chartering of insurance would be maximized, and the potential for duplicative and conflicting regulation reduced, by allowing national insurers to offer as many lines of insurance as possible. Retaining state policy form regulation for national auto and workers' compensation insurance (as contemplated by the NIA) would reduce greatly the benefits of rate deregulation for these lines. Alternatively, limiting national property/casualty insurers to commercial insurance would require them to charter separate workers compensation companies in each state in order to provide "full service." If necessary, product regulation for firms choosing a federal charter could be split between the states and the federal government, with solvency regulation taking place only at the state or federal level; however, such an approach might merely add to the inefficiencies of the existing system.

Clearly, licensing national insurers to offer certain lines, such as auto insurance, would implicate important consumer protection issues. Generally speaking, regulation of insurers, like that of banks, should be prudential in approach, and effected through the examination process. However, the more "retail" lines offered by a national insurer, the more a federal regulator would be required to promulgate market conduct regulation, 
investigate consumer complaints, enforce penalties for violations, and provide for consumer education. If such lines are offered, the federal regulator should create a distinct division of market conduct and consumer protection dedicated to retail policyholders and beneficiaries.

Furthermore, the relationship of national insurers to state residual risk mechanisms and guaranty funds must be determined. The creation of a national residual risk mechanism and a national guaranty fund would require federal administration of regulatory functions unique to insurance, and historically the province of the states. However, federal administration of these functions would enable national pooling of residual and insolvency risks, and would allow for regulatory innovations (e.g., riskbased premiums for the national guaranty fund). Indeed, either or both "pools" could be open to the participation of state chartered insurers, allowing them to enjoy any economies of scale provided by federal administration.

In summary, design of a regulatory structure for the optional federal chartering option for insurance should provide for strong and efficient federal regulation of what is a national and international financial service activity. Insofar as is possible, the federal option should give insurers the choice to be subject only to federal, rather than state, regulation and law enforcement. And, insofar as the convergence of financial services is accelerating, creation of a federal option should be a first step towards more complete consolidation of federal financial services regulation. Such a system would level the playing field both nationally and internationally, and provide consumers with the most efficient and transparent "options." 